\title{
Cutaneous mastocytoma
}

INSERM

\section{Source}

INSERM. (1999). Orphanet: an online rare disease and orphan drug data base. Cutaneous mastocytoma. ORPHA:79455

Cutaneous mastocytoma is a form of cutaneous mastocytosis (CM, see this term) generally characterized by the presence of a solitary or multiple hyperpigmented macules, plaques or nodules associated with abnormal accumulation of mast cells in the skin. 